\title{
Effects of natural extracts in the treatment of oral ulcers: A systematic review of evidence from experimental studies in animals
}

\author{
Schilin D. Wen ${ }^{1,2}$, Eulàlia Sans-Serramitjana ${ }^{1,3}$, Javiera F. Santander ${ }^{1}$, Mariela R. Sánchez ${ }^{1}$, Paulina \\ Salazar-Aguilar ${ }^{1}$, Andrea B. Zepeda ${ }^{1,4}$, Susana I. Alvarado ${ }^{1,4}$, Ignacia B. Miranda ${ }^{1,4}$ \\ ${ }^{1}$ Grupo de investigación en Ciencias Aplicadas a la Odontología, Facultad Ciencias de la Salud, Universidad Autónoma de Chile, \\ Chile \\ ${ }^{2}$ Doctoral Program in Morphological Sciences, Universidad de La Frontera, Temuco, Chile \\ ${ }^{3}$ Scientific and Technological Bioresource Nucleus (BIOREN), Universidad de La Frontera, Temuco, Chile \\ ${ }^{4}$ Non-Governmental Organization for Technology and Science Development for Humanity, Chile
}

Correspondence:

Porvenir 580, Edificio C

$4^{\circ}$ piso, Tетисо, Chile

s.wen01@ufromail.cl

\begin{abstract}
Wen SD, Sans-Serramitjana E, Santander JF, Sánchez MR, Salazar-Aguilar P, Zepeda AB, Alvarado SI, Miranda IB. Effects of natural extracts in the treatment of oral ulcers: A systematic review of evidence from experimental studies in animals. Immediate and long-term microshear bond strength of resin-based cements to core build-up materials. J Clin Exp Dent. 2021;13(10):e1038-48.
\end{abstract}

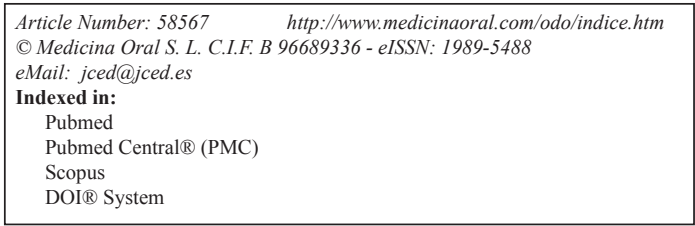

\begin{abstract}
Background: To evaluate the clinical and histopathological effects of natural extracts in the treatment of oral ulcers induced in animal experimental models.

Material and Methods: We carried out a search in the Medline, Scopus, WoS and Embase databases from the start of the databases to December 2020, and also made a manual search of the references. The search and selection were carried out by two researchers independently. The inclusion criteria were: experimental studies in animal models, in english, which complied with the study object.

Results: A total of 705 articles were identified. After selection by title, abstract and full text, 19 articles were finally included. Natural extracts of Jasminum grandiflorum, Ficus deltoidea, curcumin and Bixina orellana provoked a significantly greater reduction in the size of the ulcer. Extracts of Salvatora persica, Musa acuminate, Ganoderma lucidum mycelia and Bixina Orellana, as well as preparations of Kouyanqing Granule and curcumin, were able to reduce levels of pro-inflammatory cytokines and increase the expression and serum levels of growth factors and anti-inflammatory cytokines. Extracts of Piper sarmentosus, Cannabis sativa and Bletilla striata provoked a reduction in the severity of the histological inflammation. No significant differences were observed compared to controls in the treatments with extracts of Cannabis sativa, Aloe barbadensus Miller and Malva sylvestris in reducing the area of the oral ulcers.

Conclusions: Most of the natural extracts described in this review presented a positive clinical and histological effect on the cicatrisation of oral ulcers induced in animal models.
\end{abstract}

Key words: Recurrent aphthous stomatitis, oral ulcer, plants, herbs, extracts, medicine, treatment. 


\section{Introduction}

An oral ulcer is defined as a tissue loss that alters the epithelium and the underlying connective tissues (1). Its aetiology is related to several complex conditions developing in the oral cavity (2). Oral ulcers can be classified into acute or chronic, according to their presentation and progression; acute oral ulcers are characterized by their abrupt onset and short duration, whereas chronic ulcers are associated with slow onset and insidious progression (1). Traumatic ulcers, recurrent aphthous stomatitis, microbial infections and allergic reactions are conditions related to acute mouth ulcers (3-6). In this context, recurrent aphthous stomatitis (RAS) is considered the most common disease of the oral mucosa, with prevalence between 0.9 and $78 \%(7,8)$. The prevalence of RAS increases with higher socio-economic status and female gender $(9,10)$. The principal manifestations of this disease are small, round, painful, self-healing ulcers with circumscribed margins, erythematous haloes, and yellow or grey pseudo-membranes $(11,12)$. The management depends on the severity of the lesions, but in all cases the consensus recommendation for treatment is to reduce the pain and duration of ulcers by suppressing the local immune response and preventing secondary infection (13). Topical corticosteroids, topical anaesthetics and analgesics are commonly recommended due to the minimal occurrence of serious adverse effects. In patients with more frequent or severe forms of RAS, systemic immunosuppressive treatment is highly recommended (14); however, long-term exposure to these medications may cause drug resistance, oral flora imbalance, and secondary fungal infection $(14,15)$. In this context, there has been growing interest in the viability of natural extracts as a treatment alternative for RAS due to the lack of adverse effects $(15,16)$. Natural extracts have already proved effective for managing other oral health problems apart from ulcers, such as halitosis and bleeding gums (17), as well as systemic pathologies such as liver, cardiovascular, gastrointestinal and neurological disorders, among others (18-20). Several clinical studies have shown positive effects of natural extracts in reducing the pain and duration of mouth ulcers (21-24). Natural extracts contain several types of secondary metabolites such as flavonoids, polyphenols, and lipophilic, water-soluble polysaccharides; it has been reported that these bioactive ingredients are mainly associated with anti-adherence and anti-inflammatory effects due to their stimulation of the immune response by increasing the production of T-cells and polymorphonuclear neutrophils (PMN), as well as the activation of macrophages and monocytes (25). Although there are descriptions of the use of natural extracts for treating RAS, evidence based on experimental studies in animal models is limited. Animal models are essentially used to understand the process, mechanisms, and aetiology of a disease, as well as to check the safety, efficacy, outcome, and side effects of potential treatments $(26,27)$. The aim of this review was therefore to evaluate the clinical and histopathological effects of natural extracts in the treatment of oral ulcers induced in animal experimental models.

\section{Material and Methods}

-Review protocol

The systematic review protocol was registered in the international prospective register of systematic reviews (PROSPERO) of the National Institute for Health Research database (www.crd.york.ac.uk/prospero), reference code number CRD42020209352. This review was prepared according to the Preferred Reporting Items for Systematic Reviews and Meta-analyses (PRISMA) guideline (28).

-Search strategy

A search was carried out in the MEDLINE, WoS, SCOPUS and EMBASE databases. A manual reference search was also carried out. The database search strategy is detailed in Table 1.

-Selection criteria

The inclusion criteria were: experimental studies in animal models; in english; available from the beginning of the databases until december 2020; studies that aimed to evaluate the effect of natural extracts in the treatment of oral ulcers.

The exclusion criteria were: reviews, clinical trials, case series, case reports; published in other languages; human or in vitro studies; studies to evaluate effect of natural extracts on other pathologies of the oral mucosa.

-Study selection

All the references identified were exported to the Mendeley ${ }^{\circledR}$ reference manager to facilitate the elimination of duplicates. The articles were reviewed by two authors independently (JS, MS); when necessary, a third author (SW) resolved conflicts. Articles were selected first by title and abstract and then by full text, using the Rayyan tool.

-Data extraction

Two data extraction tables were prepared with the following information: first author and year of publication; total number of subjects and animal species; distribution of the experimental groups; method of induction of oral ulcers in animal model; type of treatment applied (Table 2, 2 cont.); natural extract used as treatment; variables evaluated and results (Table 3, 3 cont., 3 cont.-1).

-Risk of bias

Two authors (JS, MS) independently assessed the risk of bias of the articles finally included. A third author resolved conflicts (ES). The Systematic Review Center for Laboratory Animal Experimentation (SYRCLE) guideline (29) was used to assess risk of bias. 
Table 1: Search strategy.

\begin{tabular}{|c|c|c|}
\hline Databases & Search strategy & Results \\
\hline MEDLINE & $\begin{array}{l}\text { ("Plant Extracts"[Mesh] OR "Plants, Medicinal”[Mesh] OR plant extract } \\
\text { OR herbs OR medicinal herbs OR plants treatment OR herbs OR extract OR } \\
\text { "Plants, Medicinal"[Mesh] OR medicinal plants OR medicinal plants therapy } \\
\text { OR herbs theraphy OR plants therapy) AND ("Stomatitis, Aphthous"[Mesh] } \\
\text { OR stomatitis aphthous OR oral ulcer OR aphthous ulcer OR "recurrent } \\
\text { aphthous stomatitis" OR "oral Ulcer"[Mesh]) NOT "Stomach Ulcer"[Mesh] } \\
\text { NOT "gastric ulcer" } \\
\text { Filters: other animals/ english }\end{array}$ & 159 \\
\hline WoS & $\begin{array}{c}\text { ((“Plant Extracts” OR "Plants, Medicinal” OR plant extract OR herbs OR } \\
\text { medicinal herbs OR plants treatment OR herbs OR extract OR "Plants, Me- } \\
\text { dicinal” OR medicinal plants OR medicinal plants therapy OR herbs therapy } \\
\text { OR plants therapy) AND (“Stomatitis, Aphthous" OR stomatitis aphthous } \\
\text { OR oral ulcer OR aphthous ulcer OR "recurrent aphthous stomatitis” OR } \\
\text { "oral Ulcer") NOT (gastric ulcer)) } \\
\text { Filters: english }\end{array}$ & 320 \\
\hline EMBASE & $\begin{array}{l}\text { ('stomatitis aphthous’: ti,ab,kw OR aphthous:ti,ab,kw OR 'recurrent aph- } \\
\text { thous stomatitis':ti,ab,kw OR 'oral ulcer':ti,ab,kw OR aphthous:ti,ab,kw } \\
\text { OR 'aphthous ulcer':ti,ab,kw) AND (plants:ti,ab,kw OR herbs:ti,ab,kw OR } \\
\text { 'medicinal plants':ti,ab,kw OR extract:ti,ab,kw OR 'plant extract’:ti,ab,kw) } \\
\text { AND (treatment:ti,ab,kw OR therapy:ti,ab,kw) NOT gastric.:ti,ab,kw } \\
\text { Filters: english }\end{array}$ & 54 \\
\hline SCOPUS & $\begin{array}{l}\text { TITLE-ABS-KEY ((“stomatitis aphthous" OR aphthous OR “ recurrent aph- } \\
\text { thous stomatitis" OR "oral ulcer" OR aphthous OR "aphthous ulcer”) AND } \\
\text { ( plants OR herbs OR “medicinal plants" OR extract OR "plant extract" } \\
\text { ) AND ( treatment OR therapy) AND NOT gastric) AND ( LIMIT-TO } \\
\text { ( LANGUAGE, "English")) } \\
\text { Filters: english }\end{array}$ & 167 \\
\hline
\end{tabular}

Table 2: Search strategy.

\begin{tabular}{|c|c|c|c|c|}
\hline Author & Sample & Experimental group & $\begin{array}{l}\text { Oral ulcer } \\
\text { induction }\end{array}$ & $\begin{array}{c}\text { Type of } \\
\text { application }\end{array}$ \\
\hline Faruk 2020 & $\begin{array}{l}50 \text { New Zealand white } \\
\text { rabbits }\end{array}$ & $\begin{array}{l}\text { Positive control (ulcer without treat- } \\
\text { ment); SP group; LLL group; HLL group; } \\
\text { Negative control (healthy). }\end{array}$ & Acetic acid & Topic \\
\hline Mortazavi 2020 & 28 rats & JG group; Control (placebo). & Punch biopsy & Topic \\
\hline Chen 2020 & 42 Sprague-Dawley rats & $\begin{array}{l}\text { Control; Model group; KYQG-Low } \\
\text { group; KYQG-Mid group; KYQG-High } \\
\text { group; Levamisole group. }\end{array}$ & Phenol & Systemic \\
\hline Abbas 2020 & $\begin{array}{c}36 \text { New Zealand white } \\
\text { rabbits }\end{array}$ & Curcumin 1\% group; Control (placebo). & Punch biopsy & Topic \\
\hline Apriasari 2019 & 20 Wistar rats & $\begin{array}{l}\text { Control (placebo); EBPM } 25 \% \text { group; } \\
\text { EBPM 37,5 \% group; EBPM 50\% group. }\end{array}$ & Punch biopsy & Topic \\
\hline Ismail 2019 & 36 Sprague Dawley rats & Control (placebo); AEPS group. & Acetic acid & Orally \\
\hline Liao 2019 & $\begin{array}{l}20 \text { New Zealand white } \\
\text { rabbits }\end{array}$ & Control (placebo); BSP group. & Acetic acid & Topic \\
\hline
\end{tabular}


Table 2 cont.: Search strategy.

\begin{tabular}{|c|c|c|c|c|}
\hline Ernawati 2018 & 24 Wistar rats & $\begin{array}{l}\text { Control divided on days } 3,5,7,9 \text {; Propo- } \\
\text { lis groups divided on days } 3,5,7 \text {, and } 9 \text {. }\end{array}$ & Thermal injury & Topic \\
\hline Klein 2018 & 60 Wistar rats & $\begin{array}{l}\text { Control; CBD group for } 3 \text { days; CBD } \\
\text { group for } 7 \text { days. }\end{array}$ & Punch biopsy & Systemic \\
\hline El-Batal 2018 & 30 Albino mice & $\begin{array}{l}\text { Control; R group; AV group; NS group; } \\
\text { AV + NS group. }\end{array}$ & Acetic acid & Topic \\
\hline Xie 2017 & 40 Sprague Dawley rats & $\begin{array}{l}\text { Model (water); PA group; Low dose FD- } \\
\text { PGLM group; Mid dose FDPGLM group; } \\
\text { High dose FDPGLM group. }\end{array}$ & $\begin{array}{l}\text { Intradermal injec- } \\
\text { tion of an auto an- } \\
\text { tigen emulsifier. }\end{array}$ & Orally \\
\hline Ahmad 2017 & 24 Sprague Dawley rats & $\begin{array}{l}\text { Control (no treatment); Positive control } \\
\text { with } 0.1 \% \text { TCA; } 250 \mathrm{mg} \text { kg FD group; } \\
500 \mathrm{mg} \text { kg-1 FD group. }\end{array}$ & Acetic acid & Orally \\
\hline Apriasari 2016 & 20 wistar rats & $\begin{array}{l}\text { Control (EBPM 0\%); EBPM } 25 \% \text { group; } \\
\text { EBPM 37.5\% group; EBPM 50\% group. }\end{array}$ & Punch biopsy & Topic \\
\hline Oliveira 2016 & 73 Wistar rats & $\begin{array}{l}\text { Control (placebo); Negative control with- } \\
\text { out DM (NCG); Positive control with } \\
\text { DM (PCG) } \\
\text { Chamomile groups: chamomile nor- } \\
\text { moglycemic group (CNG); Chamomile } \\
\text { diabetic control group (CDCG); } \\
\text { Triamcinolone group (TG). }\end{array}$ & Abrasion & Topic \\
\hline Lim 2016 & $\begin{array}{l}20 \text { New Zealand white } \\
\text { rabbits }\end{array}$ & $\begin{array}{c}\text { Curcumin } 1 \% \text { group; control (non- } \\
\text { treated) }\end{array}$ & Acetic acid & Topic \\
\hline Coelho 2015 & 72 Wistar rats & $\begin{array}{l}\text { Control without treatment; Control (pla- } \\
\text { cebo); AV group. }\end{array}$ & Punch biopsy & Topic \\
\hline Kovalik 2014 & 136 Wistar rats & $\begin{array}{l}\text { Control; OB group; Chlorhexidine 2\% } \\
\text { group; Malva group. }\end{array}$ & Punch biopsy & Topic \\
\hline Machado 2013 & 64 Wistar rats & $\begin{array}{l}4 \text { control group treated with DMSO (for } \\
2,7,14 \text { and } 21 \text { days) and } 4 \text { groups treated } \\
\text { with bixin solution (for } 2,7,14 \text { and } 21 \\
\text { days); Negative control (healthy) }\end{array}$ & Punch biopsy & Topic \\
\hline Yu 2009 & 40 Wistar rats & $\begin{array}{l}\text { Healthy control; Model group; Low dose } \\
\text { AVP group; High dose AVP group. }\end{array}$ & Non identified & Orally \\
\hline
\end{tabular}

\section{Results}

A total of 705 articles were obtained; 47 were selected by title and abstract, and 19 articles were finally included by full text (30-48). All the studies had an experimental design in animal models and were published, in english, between 2009 and 2020. The selection process is detailed in Figure 1.

-Extracts used

The extracts used to treat oral ulcers were herbal $(34,35,39,42,43,45-48)$, the fungus Ganoderma lucidum (40), propolis $(37)$ and curcumin $(33,44)$. The plants used were of the species Musa Acuminate $(34,42)$, Aloe barbadensis Miller $(45,38,48)$, Matricaria / Chamomilla recutita
(42), Malva sylvestris (46), Piper sarmentosum (35), Jasminum grandiflorum (31), Ficus deltoidea (41), Salvadora persica (30), Cannabis sativa (38), Bletilla striata (36) and the herbal formula, Kouyanqing Granule (KYQG) (32). -Ulcer contraction

Seven studies evaluated ulcer area and/or percentage of ulcer contraction. The $57 \%$ of the studies observed a significantly smaller ulcer size in the groups treated with extracts of Jasminum grandiflorum, Ficus deltoidea, Bixa orellana and curcumin compared to controls $(31,41,44,47)$.

-Severity of inflammation

Six studies evaluated the severity and/or degree of inflammation through the presence of inflammatory cells 
Table 3: Evaluation of results.

\begin{tabular}{|c|c|c|c|}
\hline Autor & Variables & Natural extract used & Results \\
\hline Faruk 2020 & $\begin{array}{l}\text {-Expression of VEFG and BAX } \\
\text { (IHC) } \\
\text {-Tissue levels of TNF- } \alpha \text { and IL-10 } \\
\text { (ELISA) }\end{array}$ & Salvadora persica & $\begin{array}{l}\text { VEGF and BAX expression and TNF- } \alpha \\
\text { levels were lower in LLL and SP group. }\end{array}$ \\
\hline Mortazavi 2020 & $\begin{array}{l}\text { Percentage of wound contraction } \\
\qquad \text { (CA) } \\
\text {-Degree of inflammatory cell infil- } \\
\text { tration (HA) }\end{array}$ & $\begin{array}{l}\text { Jasminum } \\
\text { grandiflorum }\end{array}$ & $\begin{array}{l}\text { The percentage of wound contraction was } \\
\text { higher in the JG group than control, on day } \\
\qquad 3 \text { and } 7 \\
\text { The thickness of epithelium was greater in } \\
\text { the JG group than control on day } 7 . \\
\text { degree of inflammatory cell infiltration in } \\
\text { JG group was significantly lower on day } 7\end{array}$ \\
\hline Chen 2020 & $\begin{array}{l}\text {-Measurement of the ulcer area } \\
\text { (CA). } \\
\text {-Serum levels of TNF- } \alpha \text {, IL-1 } \beta \text {, } \\
\text { IL-6, MCP-1, ACTH, CORT, IgM, } \\
\text { 8-OHdG, GABA and 5-HT. } \\
\text {-Metabolomic profiling. }\end{array}$ & Kouyanqing Granule. & $\begin{array}{l}\text { KYQG-hight and Levamisole group showed } \\
\text { significantly higher cure rates than the mod- } \\
\text { el group (on days 7-9) } \\
\text { KYQG significantly reduced the levels of } \\
\text { 5-HT, GABA, ACTH, CORT, IgM, and } \\
\text { 8-OHdG in serum and suppressed systemic } \\
\text { inflammation by inhibiting TNF- } \alpha \text {, IL-1 } \beta \text {, } \\
\text { IL-6, IL-18, and MCP-1. } \\
\text { KYQG inhibited IL-6 expression in buccal } \\
\text { mucosa tissues. }\end{array}$ \\
\hline Abbas 2020 & -Expression of TGF $\beta$ & Curcumin & $\begin{array}{c}\text { TGF expression was significantly higher in } \\
\text { the curcumin group (day } 3 \text { and 14) }\end{array}$ \\
\hline Apriasari 2019 & $\begin{array}{l}\text {-Expression of FGF- } \beta \text { and TGF- } \beta \\
\text { (IHC) }\end{array}$ & $\begin{array}{l}\text { Mauli banana stem } \\
\text { extract (Musa } \\
\text { acuminata) }\end{array}$ & $\begin{array}{l}\text { Expression of TGF- } \beta \text { and FGF- } \beta \text { was signifi- } \\
\text { cantly higher in the EBPM } 37.5 \% \text { group. }\end{array}$ \\
\hline Ismail 2019 & -Severity of inflammation (HA) & $\begin{array}{l}\text { aqueous extracts of } \\
\text { Piper sarmentosum }\end{array}$ & $\begin{array}{c}\text { Severity of inflammation was significantly } \\
\text { lower in the AEPS group (day 2) }\end{array}$ \\
\hline Liao 2019 & $\begin{array}{l}\text {-Tensile strength, mucoadhesive } \\
\text { strength, and swelling index. }\end{array}$ & $\begin{array}{l}\text { Bletilla striata } \\
\text { polysaccharide }\end{array}$ & $\begin{array}{l}\text { The cure rate was significantly higher in the } \\
\text { BSP group (day 7) } \\
\text { No statistically significant difference on day } \\
12 .\end{array}$ \\
\hline Ernawati 2018 & $\begin{array}{c}\text {-Expression of VEGF and MMP-9 } \\
\text { (IHC) }\end{array}$ & Propolis & $\begin{array}{l}\text { The VEGF expression was higher and the } \\
\text { MMP-9 expression was lower in the propolis } \\
\text { group than the control group. }\end{array}$ \\
\hline Klein 2018 & $\begin{array}{l}\text {-Measurement of the ulcer area } \\
\qquad \text { (CA) } \\
\text {-Degree of inflammation (HA) }\end{array}$ & cannabidiol & $\begin{array}{l}\text { No significant differences in the area of the } \\
\text { ulcer between the CBD group compared to } \\
\text { the control. } \\
\text { Significantly less degree of inflammation in } \\
\text { CBD groups (day } 3 \text { ) }\end{array}$ \\
\hline
\end{tabular}


Table 3 cont.: Evaluation of results.

\begin{tabular}{|c|c|c|c|}
\hline El-Batal 2018 & $\begin{array}{c}\text {-Epithelial thickness in um (HA) } \\
\text {-Area percent of cells expressing } \\
\alpha \text {-SMA (IHC). }\end{array}$ & $\begin{array}{l}\text { Aloe barbadensis } \\
\text { miller } \\
\text { (aloe vera) }\end{array}$ & $\begin{array}{l}\text { Epithelial thickness decreased significantly } \\
\text { in Group R, Group AV, Group NS and group } \\
\qquad \text { AV + NS (day 3). } \\
\text { There was a significant reduction in the area } \\
\text { occupied by activated fibroblasts and mature } \\
\text { vascular endothelial cells in group R (day } 3 \text { ) }\end{array}$ \\
\hline Xie 2017 & $\begin{array}{c}\text {-Inflammation (HA) } \\
\text {-Serum levels of TGF- } \beta 1, \text { IL-17, } \\
\text { IL-10 and IL-6) associated with } \\
\text { LTh17 (ELISA) } \\
\text {-Percentage of CD4 + CD25 + } \\
\text { Foxp3 + Tregs and CD4 + T cells, } \\
\text { by RT-PCR. } \\
\text {-Total ulcer interval } \\
\text {-Total number of ulcers (N) } \\
\text {-ulcer area (mm2) }\end{array}$ & $\begin{array}{l}\text { Freeze-dried powder } \\
\text { from Ganoderma } \\
\text { lucidum mycelia. }\end{array}$ & $\begin{array}{l}\text { Serum levels of TGF- } \beta 1 \text { increased signifi- } \\
\text { cantly in the FDPGLM group at high doses, } \\
\text { which in turn promoted wound healing, } \\
\text { increased Foxp3 gene expression and im- } \\
\text { proved CD4 + CD25 + Foxp3 + Tregs dif- } \\
\text { ferentiation. }\end{array}$ \\
\hline Ahmad 2017 & $\begin{array}{l}\text {-Ulcer size (HA) } \\
\text {-LD50 }\end{array}$ & Ficus deltoidea & $\begin{array}{l}\text { Ulcer size (day } 6 \text { ) was significantly reduced } \\
\text { in the } 0.1 \% \text { triamcinolone acetonide group, } \\
\text { with a percentage of inhibition of } 66.5 \% \text { and } \\
\text { complete healing on day } 10 . \\
\text { The size of the ulcer was reduced and the } \\
\text { percentage of area of inhibition of the ulcer } \\
\text { increased significantly in the group treated } \\
\text { with } 250 \text { mg kg-1 of aqueous extract of F. } \\
\text { deltoidea (from day } 6 \text { ) }\end{array}$ \\
\hline Apriasari 2016 & $\begin{array}{l}\text {-Degree of FGF- } \beta \text { and TGF- } \beta \\
\text { expressions (IHC) }\end{array}$ & Musa acuminata & $\begin{array}{c}\text { TGF- } \beta \text { and FGF- } \beta \text { expression was higher in } \\
\text { the EBPM } 37.5 \% \text { group. }\end{array}$ \\
\hline Oliveira 2016 & $\begin{array}{l}\text {-Ulcer area, weight and glycemia. } \\
\text {-Histological scores (HA) } \\
\text {-Collagen deposition (HA) } \\
\text {-TNF- } \alpha \text { expression (IHC) } \\
\text {-Percentage of positive cells in } \\
\text { connective tissue and epithelium } \\
\text { (score) }\end{array}$ & $\begin{array}{c}\text { Chamomilla recutita } \\
\qquad L .\end{array}$ & $\begin{array}{l}\text { PCG showed histological scores significant- } \\
\text { ly higher than the NCG and CNG, on day } 10 . \\
\text { The PCG and CG did not differ significantly, } \\
\text { however, the TG (median=4) showed histo- } \\
\text { logical scores that were significantly higher } \\
\text { than the PCG. } \\
\text { CDG showed a significantly higher collagen } \\
\text { deposition than the PCG. }\end{array}$ \\
\hline Lim 2016 & -Ulcer area & Curcumin & $\begin{array}{l}\text { The ulcer area was significantly smaller } \\
\text { in the curcumin group than in the control } \\
\text { group, on day } 7 .\end{array}$ \\
\hline Coelho 2015 & $\begin{array}{l}\text {-Measurement of the ulcer area } \\
\text { and percentage of repair (CA) } \\
\text {-Degree of re-epithelialization and } \\
\text { inflammation (HA) }\end{array}$ & $\begin{array}{l}\text { Aloe barbadensis } \\
\text { miller (aloe vera) }\end{array}$ & $\begin{array}{l}\text { All groups showed predominantly acute } \\
\text { inflammatory infiltrate. There was partial } \\
\text { epithelialization and chronic inflammatory } \\
\text { infiltrate on day 5. On the days } 10 \text { and } 14 \text { to- } \\
\text { tal repair of ulcers was observed. There was } \\
\text { no significant difference between groups in } \\
\text { the repair of mouth ulcers. }\end{array}$ \\
\hline
\end{tabular}


Table 3 cont.-1: Evaluation of results.

\begin{tabular}{|c|c|c|c|}
\hline Kovalik 2014 & $\begin{array}{l}\text {-Wound areas measured photo- } \\
\text { graphically (CA) } \\
\text {-Re-epithelialization rates (\%) } \\
\text { (HA) }\end{array}$ & Malva sylvestris & $\begin{array}{l}\text { No significant differences in wound area or } \\
\text { re-epithelialization between the groups. } \\
\text { There was a statistically significant differ- } \\
\text { ence between the initial wound ( } 0 \text { days) and } \\
\text { the OB group at } 3 \text { days. } \\
\text { There was a statistically significant dif- } \\
\text { ference between the initial wound and the } \\
\text { Malva } 20 \% \text { group at } 7 \text { days. }\end{array}$ \\
\hline Machado 2013 & $\begin{array}{l}\text {-Fibroblasts, re-epithelialization } \\
\text {-Cell count } \\
\text {-Wound contraction (CA) }\end{array}$ & $\begin{array}{l}\text { Bixa orellana L. } \\
\text { (urucum) }\end{array}$ & $\begin{array}{l}\text { Fibroblast proliferation, re-epithelialization } \\
\text { and wound contraction at day } 7 \text { were higher } \\
\text { in groups treated with bixin. } \\
\text { Greater reduction in the average number of } \\
\text { neutrophils in bixin groups, in all periods. } \\
\text { The deposition of mature collagen, at day } \\
\text { 14, was greater in bixin groups than in con- } \\
\text { trol. }\end{array}$ \\
\hline Yu 2009 & $\begin{array}{l}\text {-Ratio of CD4 + / CD8 T cells } \\
\text { (flow cytometry) } \\
\text {-IL-2, IFN, ET-1 in plasma and } \\
\text { mucosa, IgG, IgA and IgM levels } \\
\text { (ELISA) } \\
\text {-SOD activity and the level of } \\
\text { MDA (ELISA) }\end{array}$ & $\begin{array}{l}\text { Aloe barbadensis } \\
\text { miller (aloe vera) }\end{array}$ & $\begin{array}{l}\text { AVP groups reduced the LTCD4 + / LTCD8 } \\
+ \text { ratio compared to the model group. } \\
\text { AVP groups showed a significant increase in } \\
\text { IL-2 and IFN-c levels and in plasma levels } \\
\text { of IgG, IgA and IgM compared to the model } \\
\text { group. } \\
\text { AVP groups showed a significant decrease } \\
\text { in ET-1 levels in plasma and mucosa com- } \\
\text { pared to the model group. } \\
\text { AVP groups had significant improvement } \\
\text { in SOD activity and reduced MDA level in } \\
\text { plasma compared to model rats. }\end{array}$ \\
\hline
\end{tabular}

SP: Salvadora pérsica; LLL: low-level laser; HLL: high-level laser; JG: Jasminum grandiflorum; KYQG: kouyanqing granule; EBMP: mauli banana stem extract (Musa Acuminate); AEPS: aqueous extract of Piper sarmentosum; BSP: Bletilla Striata polysaccharide; AV: aloe vera (Aloe barbadensis miller); NS: silver nanoparticles; AVP: aloe vera polysaccharides; PA: prednisone acetate; FDPGLM: freeze-dried powder from Ganoderma lucidum mycelia; FD: Ficus deltoidea; TCA: triamcinolone acetonide; DM: diabetes mellitus; OB: orabase vehicule; DMSO: dimethyl sulfoxide; CBD: cannabidiol; R: radiation; NCG: negative control group; PCG: positive control group; CNG: chamomile normoglycemic group; CDCG: chamomile diabetic control group; TG: triamcinolone group; IHC: immunohistochemical staining; CA: clinical analysis; HA: histological analysis; TNF- $\alpha$ : tumor necrosis factor; IL: interleukin; MCP-1: monocyte chemoattractant protein 1; ACTH: adrenocorticotropic hormone; CORT: corticosterone; Ig: immunoglobulin; 8-OHdG: 8- hydroxy-deoxyguanosine; GABA: $\gamma$-aminobutyric acid; 5-HT: 5- hydroxytryptamine; FGF- $\beta$ : fibroblast growth factor- $\beta$; TGF- $\beta$ : transforming growth factor - $\beta$; VEGF: vascular endothelial growth factor; MMP-9: matrix metalloproteinase-9; $\alpha$-SMA: alpha-smooth muscle actin; LTh17: lymphocytes t helper 17; IFN- $\gamma$ : interferon gamma; ET-1: endotelina; SOD: superoxide dismutase; MDA: malondialdehyde; ELISA: enzyme-linked immunosorbent assay; RT-PCR: real-time polymerase chain reaction; LD50: dose necessary to kill half of the members of a population tested in the specified duration.

and re-epithelialization. The $66 \%$ of the studies observed a significantly lower severity/degree of inflammation in the groups treated with extracts of Jasminum grandiflorum, Piper sarmentosum, Cannabis sativa and Bixa orellana compared to the controls $(31,35,38,47)$.

-Molecular expression

TGF- $\beta$ expression was significantly higher in ulcers treated with extracts of curcumin and Musa acuminata $(33,34,40)$ compared to controls. The serum level of TGF- $\beta$ was also significantly higher in the group treated with Ganoderma lucidum extract, compared to the control group (42). TNF- $\alpha$ expression was significantly lower in ulcers treated with extracts of Chamomilla recutita, Salvadora persica and Koyanqing Granule formula, compared to controls $(30,32,44)$. VEGF expression was significantly lower in ulcers treated with Salvadora persica extract and higher in ulcers treated with propolis extract, compared to their respective controls $(30,37)$. The expression of MMP-9 was significantly lower in the ulcers treated with propolis extract, compared to the control group (37). Serum levels of IL-1 $\beta$, IL-6, IL-18 were significantly reduced in the group treated with Kouyaqing Granule formula compared to the control group (32). 


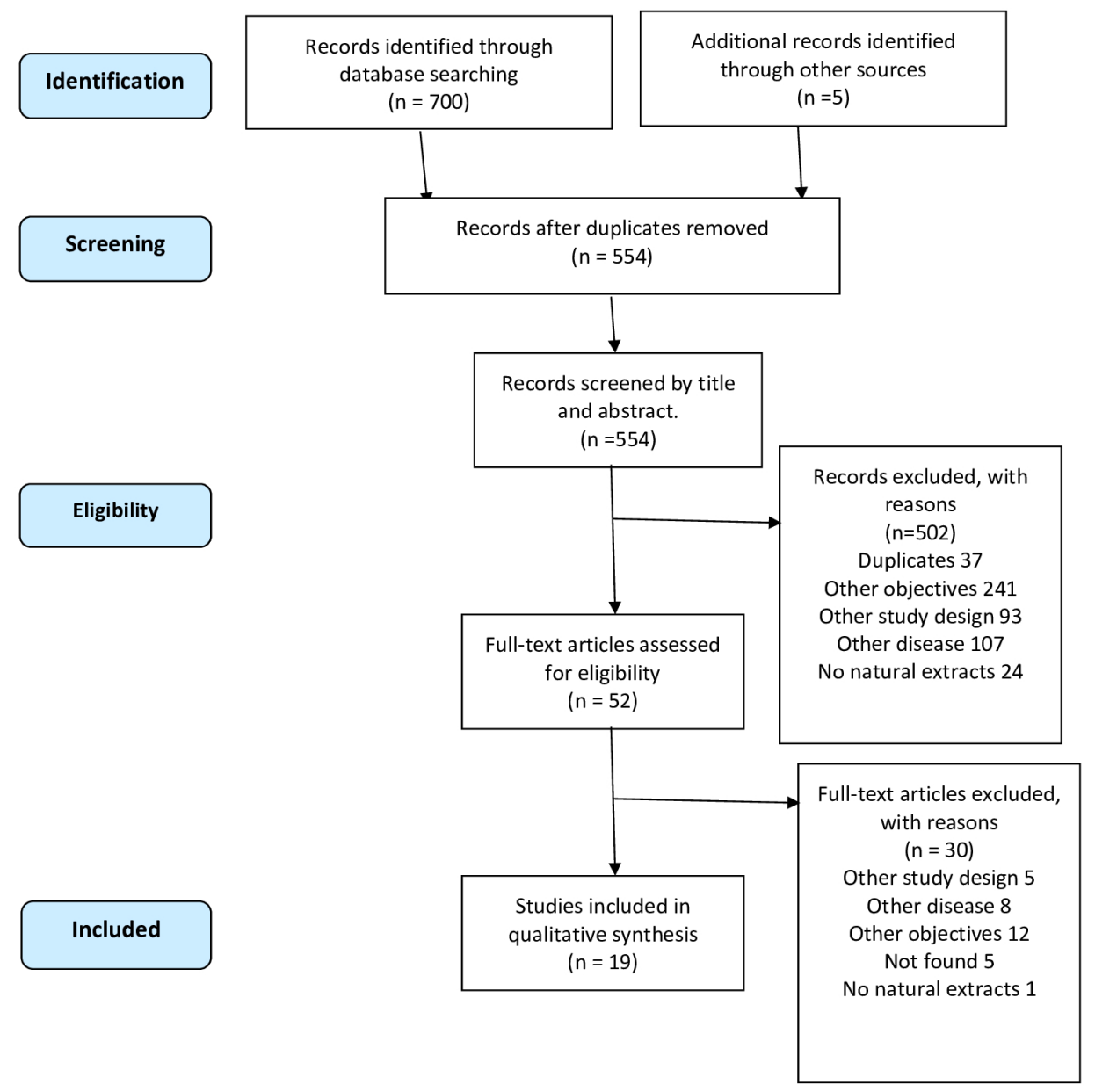

Fig. 1: PRISMA Flow Diagram.

-Risk of bias

The results of the risk of bias evaluation in the studies selected are shown in Figures 2 and 3.

\section{Discussion}

It has been proposed that natural extracts present multiple health benefits, and can be used effectively for the-



Fig. 2: The results of the risk of bias evaluation. 


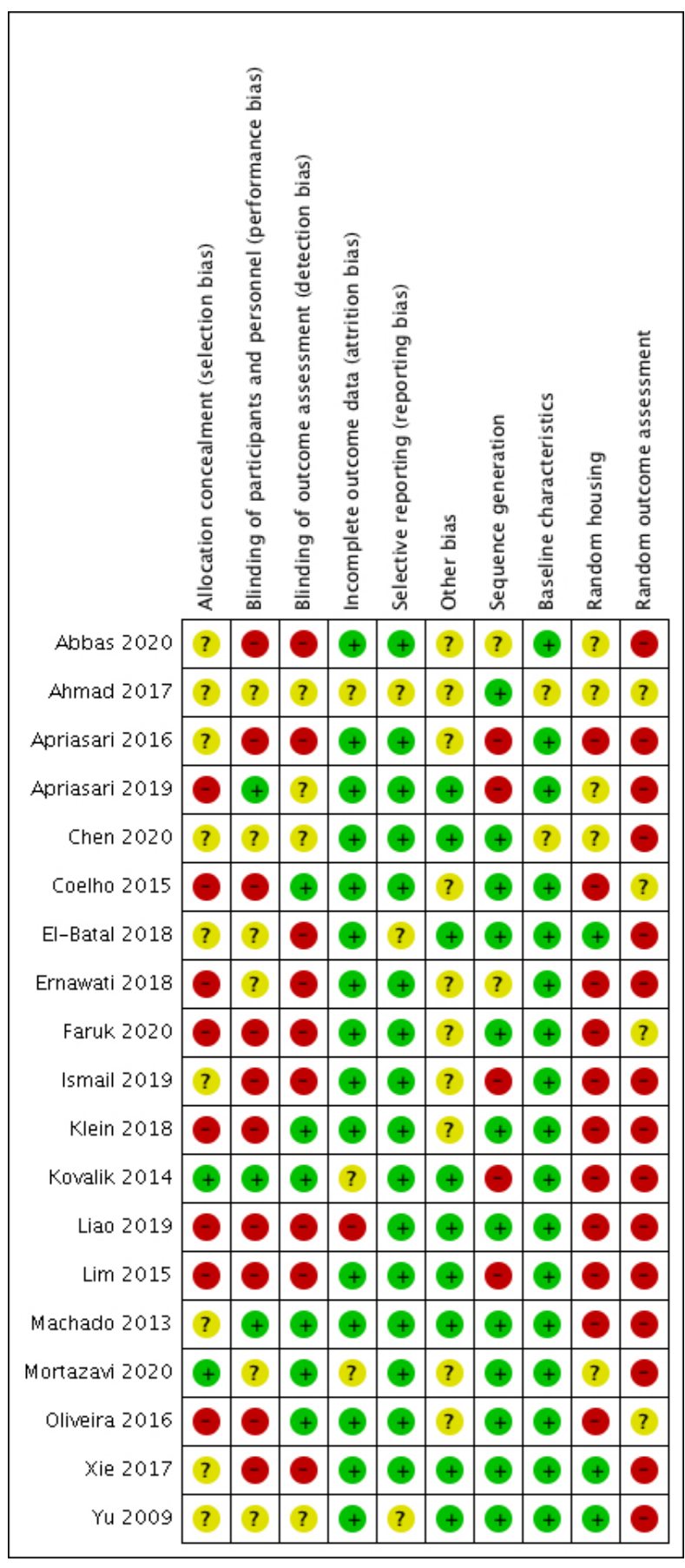

Fig. 3: The results of the risk of bias evaluation.

rapeutic ends (49). It is therefore important to consider the scientific evidence available to support their use in the treatment of different diseases. The physiopathology of oral ulcers is complex and comprises vasodilatation, cytokine production, cell death, and tissue repair and remodelling (50). Observations at the molecular level include over-expression of VEGF; over-expression of BAX; marked deposit of collagen fibers in the repair process $(30,37)$; and an increase in both pro-inflammatory and anti-inflammatory cytokines $(30,32,37,40,43,48)$.
The $84 \%$ of the studies selected reported a positive effect of the treatments on the variables evaluated. The treatments based on curcumin, Musa acuminata and the fungus Ganoderma lucidum showed higher serum levels of TGF- $\beta$ in comparison with the control groups (ulcers treated with placebo). TGF- $\beta$ is a cytokine that stimulates the formation of granulation tissue, improves the angiogenic properties of the endothelial progenitor cells to facilitate delivery of blood to the site of the lesion, inhibits matrix metalloproteinase (MMP) and stimulates myofibroblast contraction to allow the wound to close (51).

Extract of the plant Salvadora persica was effective in the repair of induced oral ulcers, provoking a smaller expression of VEGF, TNF- $\alpha$ and IL-10 (30). The propolis-based treatment provoked greater expression of VEGF and smaller expression of MMP-9 in induced oral ulcers (37). This difference in VEGF levels could be explained by the fact that diabetes mellitus (DM) was also induced in these rats, a metabolic pathology in which VEGF levels diminish and MMP-9 levels increase, altering the cicatrisation process (37). Topical propolis gel extract therefore increased the VEGF expression necessary for the repair process, and decreased MMP-9, indicating the presence of angiogenesis; it also decreased collagen degradation, accelerating wound-healing in ulcers in the DM-afflicted rat model.

KYQG is a formulation belonging to traditional Chinese medicine, made up from five different plant species. The rats treated with KYQG were also deprived of sleep for $72 \mathrm{hrs}$. It was observed that KYQG inhibited the serum levels of IL-1, IL-18, IL-6, monocyte chemoattractant protein 1 (MCP-1) and IL-6 in tissues, and the excessive release of adrenocorticotropic hormone (ACTH) and corticosterone (CORT). It has been shown that lack of sleep can activate the hypothalamus pituitary adrenal (HPA) axis (52). KYQG has also been described as regulating (decreasing) serum levels of $\gamma$-aminobutyric acid (GABA) and 5-hydroxytryptamine (5-HT), but it can only diminish the level of 5-HT in the brain. 5-HT is an important pronociceptive mediator which can induce inflammation, hyperalgesia and/or allodynia (43). Extract of Malva sylvestris at 20\% produced no significant reduction in the area of the oral ulcer, and no positive effect on re-epithelialization of the palatal mucosa in comparison with the control group treated with placebo (46). Extracts of Jasminum grandiflorum (29), Bixina orellana (45), Musa acuminata stem $(32,40)$, Bletilla striata (34), curcumin (42), Ficus deltoidea, and Piper sarmentosum were effective in accelerating the repair process; authors observed greater contraction of the ulcer, greater re-epithelialization $(31,31,44,47)$, greater production of factors which accelerate cicatrisation (34), less severe inflammation (37), and better healing rates on days $7(36,44)$ and $14(44)$. The results with no 
significant differences obtained by Kovalik et al. may be because the animals were kept awake and fed normal food, which could have generated extra mechanical and physical trauma due to mastication. Furthermore, the application of Orabase alone would produce better adherence than the Malva extract gel used (46). Extract of Bixina orellana provoked a reduction of neutrophils (cells which secrete elastase, an enzyme that degrades the extracellular matrix (ECM) (47). Treatment with Aloe Vera at $0.5 \%$ was not effective in accelerating cicatrisation. This may be explained by the fact that oral mucosa heals more quickly than skin, and perhaps the low concentrations of Aloe Vera are insufficient to stimulate faster recovery in the oral epithelium, which tends to have a much higher basic proliferation index (45). Cannabidiol was able to inhibit chemotaxis and neutrophil proliferation; an anti-inflammatory effect was observed only in the early stage of repair (day 3 after induction of the ulcer), however it did not produce a significant difference in the area of the ulcer. In the initial stage of inflammation, neutrophils release pro-inflammatory cytokines, like TNF- $\alpha$ and IL- $\beta$, responsible for increasing vascular permeability, oedema and chemotaxis of the neutrophils; however, their over-expression and production in diabetic patients is related with increased inflammation and delayed cicatrisation of ulcers (38). Freeze-dried powder from G. lucidum mycelia (FDPGLM) in high doses reduced the number and area of oral ulcers induced in rats, increasing significantly the serum levels of TGF- $\beta$ 1 , which in turn promoted cicatrisation of the lesions, increased expression of the Foxp3 gene and improved levels of the lymphocytes CD4+ and CD25+ (40). The majority of the studies analysed in this review report satisfactory results from the use of natural extracts in the treatment of oral ulcers. Their effects are related with reductions in pain and ulcer size, and faster healing. The consensus recommendation for the treatment of oral ulcers is to reduce pain and the duration of the ulcer by suppressing the local immune response and preventing secondary infection $(8,13)$. It is also observed that the principal advantage of using natural extracts is that, unlike their synthetic and chemical counterparts, they do not cause any important secondary effects. For this reason, patients nowadays are tending to change their lifestyles and use natural extracts as a suitable alternative treatment for oral ulcers.

\section{Conclusions}

Extracts of Jasminum grandiflorum, Bletilla striata, Ficus deltoidea, curcumin, Bixina orellana, Chamomilla recutita and Musa acuminate provoked a positive effect in ulcer contraction, re-epithelialization, and serum levels of molecules that promote repair or accelerate the healing rate. No significant differences from the control groups were observed with the use of treatments based on cannabidiol, Aloe Vera and Malva sylvestris in the area of the oral ulcers.

\section{References}

1. Muñoz-Corcuera M, Esparza-Gómez G, González-Moles MA, Bascones-Martínez A. Oral ulcers: clinical aspects. A tool for dermatologists. Part I. Acute ulcers. Clin Exp Dermatol. 2009;34:289-94.

2. Field EA, Allan RB. Review article: oral ulceration--aetiopathogenesis, clinical diagnosis and management in the gastrointestinal clinic. Aliment Pharmacol Ther. 2003;18:949-62.

3. Slebioda Z, Szponar E, Kowalska A. Etiopathogenesis of recurrent aphthous stomatitis and the role of immunologic aspects: literature review. Arch. Immunol. Ther. Exp. 2014;62:205-215.

4. Thakrar P, Chaudhry SI. Oral Ulceration: An Overview of Diagnosis and Management. Prim Dent J. 2016;5:30-33.

5. Altenburg A, El-Haj N, Micheli C, Puttkammer M, Abdel-Naser MB, Zouboulis CC. The treatment of chronic recurrent oral aphthous ulcers. Dtsch Arztebl Int. 2014;111:665-73.

6. Siu A, Landon K, Ramos DM. Differential diagnosis and management of oral ulcers. Semin Cutan Med Surg. 2015;34:171-7.

7. Rivera C. Essentials of recurrent aphthous stomatitis. Biomed Rep. 2019;11:47-50.

8. Scully C, Porter S. Oral mucosal disease: recurrent aphthous stomatitis. Br J Oral Maxillofac Surg. 2008;46:198-206.

9. Tappuni AR, Kovacevic T, Shirlaw PJ, Challacombe SJ. Clinical assessment of disease severity in recurrent aphthous stomatitis. J Oral Pathol Med. 2013;42:635-41.

10. Bruce AJ, Rogers RS 3rd. Acute oral ulcers. Dermatol Clin. 2003;21:1-15.

11. Rennie JS, Reade PC, Hay KD, Scully C. Recurrent aphthous stomatitis. Br Dent J. 1985;159:361-7.

12. Eisen D, Carrozzo M, Bagan JV, Thongprasom K, Number V. Oral lichen planus: clinical features and management. Oral Dis. 2005; 11:338-349.

13. Ghalayani P, Zolfaghary B, Farhad AR, Tavangar A, Soleymani B. The efficacy of Punicagranatum extract in the management of recurrent aphthous stomatitis. J Res Pharm Pract. 2013;2:88-92.

14. Femiano F, Lanza A, Buonaiuto C, Gombos F, Nunziata M, Piccolo $\mathrm{S}$, et al. Guidelines for diagnosis and management of aphthous stomatitis. Pediatr Infect Dis J. 2007;26:728-732.

15. Vaishnavi V. Management of recurrent aphthous stomatitis - A review. Res J Pharm Tech. 2014;7:1193-5.

16. Rattan J, Schneider M, Arber N, Gorsky M, Dayan D. Sucralfate suspension as a treatment of recurrent aphthous stomatitis. J Intern Med. 1994;236:341-343.

17. Chandra Shekar BR, Nagarajappa R, Suma S, Thakur R. Herbal extracts in oral health care - A review of the current scenario and its future needs. Pharmacogn Rev. 2015;9:87-92.

18. Rastogi S, Pandey MM, Rawat AK. Traditional herbs: a remedy for cardiovascular disorders. Phytomedicine. 2016;23:1082-9.

19. Tan N, Gwee KA, Tack J, Zhang M, Li Y, Chen M, et al. Herbal medicine in the treatment of functional gastrointestinal disorders: A systematic review with meta-analysis. J Gastroenterol Hepatol. 2020;35:544-556.

20. Pohl F, Kong Thoo Lin P. The Potential Use of Plant Natural Products and Plant. Extracts with Antioxidant Properties for the Prevention/Treatment of Neurodegenerative Diseases: In Vitro, In Vivo and Clinical Trials. Molecules. 2018;23:3283.

21. Liu X, Guan X, Chen R, Hua H, Liu Y, Yan Z. Repurposing of yunnan baiyao as an alternative therapy for minor recurrent aphthous stomatitis. Evid Based Complement Alternat Med. 2012;2012:284620. 22. Gavanji S, Larki B, Bakhtari A. The effect of extract of Punicagranatum var. pleniflora for treatment of minor recurrent aphthous stomatitis. Integr Med Res. 2014;3:83-90.

23. Jiang XW, Zhang Y, Zhu YL, Zhang H, Lu K, Li FF, et al. Effects of berberine gelatin on recurrent aphthous stomatitis: a randomized, placebo-controlled, double-blind trial in a Chinese cohort. Oral Surg Oral Med Oral Pathol Oral Radiol. 2013;115:212-217. 
24. Haghpanah P, Moghadamnia AA, Zarghami A, Motallebnejad M. Muco-bioadhesive containing ginger officinal e extract in the management of recurrent aphthous stomatitis: A randomized clinical study. Caspian J Intern Med. 2015;6:3-8.

25. Allegra M. Antioxidant and Anti-Inflammatory Properties of Plants Extract. Antioxidants (Basel). 2019;8:549.

26. Sena ES, Currie GL, McCann SK, Macleod MR, Howells DW. Systematic reviews and meta-analysis of preclinical studies: Why perform them and how to appraise them critically. Journal of Cerebral Blood Flow \& Metabolism. 2014;34:737-74

27. Franco NH. Animal Experiments in Biomedical Research: A Historical Perspective. Animals (Basel). 2013;3:238-273.

28. Moher D, Liberati A, Tetzlaff J, Altman DG, The PRISMA Group. Preferred Reporting Items for Systematic Reviews and Meta-Analyses: The PRISMA Statement. PLoS Med. 2009;6:e1000097.

29. Hooijmans CR, Rovers MM, de Vries RB, Leenaars M, Ritskes-Hoitinga M, Langendam MW. SYRCLE's risk of bias tool for animal studies. BMC Med Res Methodol. 2014;14:43.

30. Faruk EM, Nafea OE, Fouad H, Ebrahim UFA, Hasan RAA. Possible healing effects of Salvadora persica extract (MISWAK) and laser therapy in a rabbit model of a caustic-induced tongue ulcers: histological, immunohistochemical and biochemical study. J Mol Histol. 2020;51:341-352.

31. Mortazavi H, Mashhadiabbas F, Mortazavi S, Rezaeifar K, Farhangi M. Formulation of a Jasmine Grandiflorum containing mucoadhesive and evaluation of its healing effect on oral biopsy ulcers. Clinical Oral Investigations. 2020;24:1591-1597.

32. Chen P, Yao H, Su W, Zheng Y, Fan W, Zhang L, et al. Pharmacodynamic and Metabolomics Studies on the Effect of Kouyanqing Granule in the Treatment of Phenol-Induced Oral Ulcer Worsened by Sleep Deprivation. Front Pharmacol. 2020;11:824.

33. Abbas MS, Fadhil T. Curcumin Modulate TGF $\beta$ ii-R to Improve Healing of Oral Ulceration. International Journal of Pharmaceutical Research. 2020.

34. Apriasari M, Pramitha S, Puspitasari D, Ernawati D. Expression of fibroblast growth factor- $\beta$ and transforming growth factor- $\beta$ in mauli banana stem (Musa acuminate) extract gel-treated traumatic ulcer. Tropical Journal of Pharmaceutical Research. 2019; p. 527-531.

35. Ismail M, Mohd N. The effect of Piper sarmentosum aqueous extract on buccal ulcer healing. Journal of Health and Translational Medicine. 2019;22.

36. Liao Z, Zeng R, Hu L, Maffucci KG, Qu Y. Polysaccharides from tubers of Bletilla striata: Physicochemical characterization, formulation of buccoadhesive wafers and preliminary study on treating oral ulcer. Int J Biol Macromol. 2019;122:1035-1045.

37. Ernawati DS, Sari AP. Expression of vascular endothelial growth factor and matrix metalloproteinase-9 in Apis mellifera Lawang propolis extract gel-treated traumatic ulcers in diabetic rats. Veterinary World. 2018;11:304-309.

38. Klein M, de Quadros De Bortolli J, Guimarães FS, Salum FG, Cherubini K, de Figueiredo MAZ. Effects of cannabidiol, a Cannabis sativa constituent, on oral wound healing process in rats: Clinical and histological evaluation. Phytother Res. 2018;32:2275-2281.

39. El-Batal A, Ahmed S. Therapeutic effect of Aloe vera and silver nanoparticles on acid-induced oral ulcer in gamma-irradiated mice. Brazilian Oral Research. 2018;32:e04.

40. Xie L, Zhong X, Liu D, Liu L, Xia Z. The effects of freeze-dried Ganoderma lucidum mycelia on a recurrent oral ulceration rat model. BMC Complementary and Alternative Medicine. 2017;17:511.

41. Ahmad V, Amin I. Anti-Oral Ulcer Activity of Ficus deltoidea Leaves Extract on Animal Model. Science \& Technology. 2017;25:41-52. 42. Apriasari M, Dachian Y, Ernawati D. Effect of Musa acuminata Stem By Immunohistochemistry Test in Ulcer. Asian Journal of Biochemistry. 2016;11:135-141.

43. Oliveira BV, Barros Silva PG, Nojosa Jde S, Brizeno LA, Ferreira JM, Sousa FB, et al. TNF-alpha expression, evaluation of collagen, and TUNEL of Matricaria recutita L. extract and triamcinolone on oral ulcer in diabetic rats. J Appl Oral Sci. 2016;24:278-90

44. Lim YS, Kwon SK, Park JH, Cho CG, Park SW, Kim WK. En- hanced mucosal healing with curcumin in animal oral ulcer model. Laryngoscope. 2016;126:E68-73.

45. Coelho F, Salvadori G, Varvaki P, Magnusson A, Krebs C, Meurer L et al. Topical Aloe Vera (Aloe barbadensis miller) Extract Does Not Accelerate the Oral Wound Healing in Rats. Phytotherapy Research. 2015;29:1102-5.

46. Kovalik A, Bisetto P, Pochapski M, Campagnoli E, Pilatti G, Santos F. Effects of an Orabase Formulation with Ethanolic Extract of Malva sylvestris L. in Oral Wound Healing in Rats. Journal of Medicinal Food. 2014;17:618-24.

47. Piva RM, Johann AC, Costa CK, Miguel OG, Rosa ER, de Azevedo-Alanis LR, et al. Bixin action in the healing process of rats mouth wounds. Curr Pharm Biotechnol. 2013;14:785-91.

48. Yu Z, Jin C, Xin M, JianMin H. Effect of Aloe vera polysaccharides on immunity and antioxidant activities in oral ulcer animal models. Carbohydrate Polymers. 2009;75:307-311.

49. Al-Ayed MS, Asaad AM, Qureshi MA, Attia HG, AlMarrani AH. Antibacterial activity of Salvadora persica L. (Miswak) extracts against multidrug resistant bacterial clinical isolates. Evid Based Complement Alternat Med. 2016;2016:7083964.

50. Campisi G, Compilato D, Cirillo N, Ciavarella D, Panzarella V, Amato S, et al. Oral ulcers: three questions on their physiopathology. Minerva Stomatol. 2007;56:293-302.

51. White LA, Mitchell TI, Brinckerhoff CE. Transforming growth factor beta inhibitory elements in the rabbit matrix metalloproteinase-1 (collagenase-1) gene functions as a repressor of constitutive transcription. Biochim Biophys Acta. 2000;1490:259.

52. Opp MR, Krueger JM. Sleep and immunity: A growing field with clinical impact. Brain Behav Immun. 2015;47:1-3.

53. Askin R, Sasaki M, Goto M. Recovery of water-soluble compounds from Ganoderma lucidum by hydrothermal treatment. Food Bioprod Process. 2010;88:291-7.

54. Bhardwaj N, Katyal P, Sharma AK. Suppression of inflammatory and allergic responses by pharmacologically potent fungus Ganoderma lucidum. Recent Patents Inflamm Allergy Drug Discov. 2014;8:104-17 55. Cheng S, Sliva D. Ganoderma lucidum for cancer treatment: we are close but still not there. Integr Cancer Ther. 2015;14:249-57.

56. Gao Y, Tang W, Gao H, Chan E, Lan J, Zhou S. Ganoderma lucidum polysaccharide fractions accelerate healing of acetic acid-induced ulcers in rats. J Med Food. 2004;7:417-21.

57. Hasnat MA, Pervin M, Cha KM, Kim SK, Lim BO. Anti-inflammatory activity on mice of extract of Ganoderma lucidum grown on rice via modulation of MAPK and NF-kappa B pathways. Phytochemistry. 2015;114:125-36.

58. Liu C, Dunkin D, Lai J, Song Y, Ceballos C, Benkov K, Li X. Anti-inflammatory effects of Ganoderma lucidum Triterpenoid in human Crohn's disease associated with Downregulation of NF-kappaB signaling. Inflamm Bowel Dis. 2015;21:1918-25.

59. Koray M, Ak G, Kürklü E, Tanyeri H, Aydin F, Oguz FS, et al. The effect of $\beta$-Glucan on recurrent Aphthous Stomatitis. J Altern Complement Med. 2009;15:111-2.

\section{Conflicts of interest}

The authors of this review declare that there is no conflict of interest. 